\title{
高温におけるフロートガラスの熱伝導率のニードルプローブ法による測定
}

\author{
幾世橋 廣 $\cdot$ 早川直也* ·荒谷眞一 $*$ 増田英俊** \\ 東北大学大学院工学研究科地球工学専攻，980-8579 仙台市青葉区荒巻字青葉 01 \\ *セントラル硝子(株)硝子研究所，515-0001 三重県松阪市大口町 1510 \\ **東北学院大学工学部, 985-8537 宮城県多賀城市中央 1-13-1
}

\section{Thermal Conductivity Measurements of Float Glass at High Temperatures by Needle Probe Method}

\author{
Hiroshi KIYOHASHI, Naoya HAYAKAWA, ${ }^{*}$ Shin'ichi ARATANI* and Hidetoshi MASUDA** \\ Department of Geoscience and Technology, Graduate School of Engineering, Tohoku University, \\ 01, Aza-Aoba, Aramaki, Aoba-ku, Sendai-shi 980-8579 \\ ${ }^{*}$ Glass Research Center, Central Glass Co., Ltd., 1510, Ohkuchi-cho, Matsusaka-shi, Mie 515-0001 \\ **Faculty of Technology, Tohoku Gakuin University, 1-13-1, Chuo, Tagajo-shi, Miyagi 985-8537
}

\begin{abstract}
Thermal conductivity of several soda-lime-silicate glasses, which are called float glasses, has been measured by a needle probe method in the temperature ranges from room temperature to $1173 \mathrm{~K}$. Kinds of the samples were the ordinary clear float glass (CFL), bronze (BFL), gray (GFL), blue (HFL) and green (MFL) glasses. Experimental results showed that the thermal conductivity of the glasses increased gradually with rise of temperature in the ranges from room temperature to $1173 \mathrm{~K}$. Thermal conductivity values of the glasses measured do not depend on the kinds of samples, and it is considered that the measured values are real thermal conductivity. The values of conductivity of the glasses measured were about $1.0 \mathrm{~W} /(\mathrm{m} \cdot \mathrm{K})$ at $303 \mathrm{~K}, 1.3 \mathrm{~W} /(\mathrm{m} \cdot \mathrm{K})$ at $773 \mathrm{~K}, 1.4 \mathrm{~W} /(\mathrm{m} \cdot \mathrm{K})$ at $973 \mathrm{~K}$ and $1.7 \mathrm{~W} /(\mathrm{m} \cdot \mathrm{K})$ at $1173 \mathrm{~K}$.
\end{abstract}

[Received August 5, 1999; Accepted February 16, 2000]

Key-words : Thermal conductivity, Soda-lime-silicate glass, Float glass, Needle probe method, High temperature

\section{1. 緒言}

ガラスの熱伝導率測定に関しては,レーザーフラッシュ法を 始めとして多くの測定方法が提案されており1),2)，多くの知見 が得られている。ガラス内の熱伝導は構成原子あるいはイオン の格子振動に基づくフォノンによる伝熱であり ${ }^{3), 4)}$, 熱伝導率 はそのガラス組成に依存するとされている。この熱伝導率に対 するガラス組成の依存性については, 多くの研究者により研究 され，その加成式も提案されている5 ${ }^{5), 6)}$.

しかし, その熱伝導率は室温近傍の測定值がほとんどであ り, 高温状態で実際に測定された例は極めて少ない。また，熱 伝導率に対しては, 前述したようにそのガラス組成が重要であ るにもかかわらず，そのガラス組成が明記されていない場合が 多い。特に，フロートガラスと称されるソーダ・ライム・シリ カガラスは建築用や自動車の空ガラスを始めとして広く使用さ れているにもかかわらず, $770 \mathrm{~K}$ を超える温度域では, 測定例 は極めて少ない。例えば, Ratcliffe ${ }^{6)}$ は種々のガラスの熱伝導 率を加成律屯で含めてかなり詳細に報告しているが，その中心 は室温やそれ以下の低温領域におけるものであり, 高温域では $473 \mathrm{~K}$ に抢ける測定データが示されている程度である。荒木 ら7)はステップ状加熱法による $973 \mathrm{~K}$ までの熱伝導率測定結果 を報告して招り，有用な情報を与えてくれるが，透明なフロー トガラス 1 種類の值だけである.

高温領域においては，杉山ら ${ }^{8)} 01373 \mathrm{~K}$ におけるびんガラ スの輻射伝熱の研究があり, 最近では Sasaki ら99のホウケイ 酸塩ガラス（パイレックス）の放射率測定報告がある。また， Henderson ら ${ }^{10)}$ は熱伝導率を推定するとき，その温度勾配を 求める位置によりその值が異なることを示している。しかし， これらの研究で得られた值は, 見掛けの熱伝導率（=真の熱伝 導率十輻射熱伝導率) であり，いわゆる真の熱伝導率ではな い。一方, Yu ら ${ }^{11)}$ は細線加熱法により, K9 と称される光学
ガラスの $1100 \mathrm{~K}$ までの熱伝導率を測定しているが，1 種類の 試料だけで，その信頼性についても不明である。

高温状態でのガラスの熱伝導率がまだ測定されていない大き な理由は，例えば温度が転移点よりも高くなると，それまでの 伝導伝熱に加えて対流伝熱や輻射伝熱も関与してくるからであ る。一般に，ガラスは市る波長域で輻射に対して半透明である ため，外部からの輻射エネルギーを受け入れ，内部で発生した 輻射エネルギーは移動する．高温になるほどこの傾向は大きく なるので, 得られた熱伝導率值の評価は難しくなる。ガラスの 熱伝導率に関し, 古くは Genzel ${ }^{12}$ )が輻射伝導率を計算から求 めているが，実際の測定值を報告していないので，その値が真 の值に近いとは断言できない。また，輻射性媒体の熱伝導率測 定に関し，Hot-wire 法で測定したときの輻射輸送の影響が報 告13)されているが，これは微粉体とか多孔体エアロゲルのよ うな低密度媒体を対象としたものである。したがって，高温域 のガラスに拈ける熱伝導率の測定結果や推算值に対する信頼性 は十分とはいえないのが実状である。このような現状を踏をえ て，ほぼ同じ組成で，かつ各波長での透過・吸収特性の異なる 性質をもったガラスについて検討を行えば，上述の問題を明ら かにできる可能性がある。プローブ法14)や細線加熱法 ${ }^{15)}$ は対 流伝熱の影響を除去できるので, 溶融状態のガラスにも適用で きるほか，絶対法であるため，その算出に他の物性值が必要な いという長所がある。

そこで，本研究では透明なフロートガラス及びそれと主成分 がほぼ同様な 4 種類の着色ガラスを試料とし, プローブ法に よりそれぞれのガラスの熱伝導率を室温から $1173 \mathrm{~K}$ なでの温 度範囲で測定した。 


\section{2. 実 験}

\section{1 測定原理}

熱伝導率が $\lambda$, 熱拡散率（又は温度伝導率）が $a$, 温度が $\theta_{\infty}$ で一様な等方性無限媒体中に, 直径が無限小の細長い発熱体を 置き, 単位長さ単位時間当たり $q$ の熱量を発生させたとき, $r$ だけ離れたところにおける $t \mathrm{~s}$ 後の温度 $\theta$ は次式

$$
\theta-\theta_{\infty}=-\left(\frac{q}{4 \pi \lambda}\right) E_{\mathrm{i}}\left(\frac{-r^{2}}{4 a t}\right)
$$

で与えられる15),16)。ここで，

$$
-E_{\mathrm{i}}(-x)=\int_{x}^{\infty}\left(\frac{e^{-\mathrm{u}}}{u}\right) \mathrm{d} u
$$

である. $\left(r^{2} / 4 a t\right) \ll 1 の$ 場合，(1)式は

$$
\theta-\theta_{\infty}=\left(\frac{q}{4 \pi \lambda}\right)\left\{\ln \left(\frac{4 a t}{r^{2}}\right)-\gamma\right\}
$$

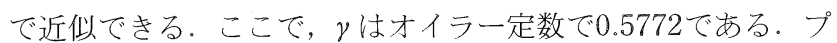
ローブ表面の温度を $\theta$, プローブの半径を $r_{0}$ とし, 時間 $t_{1}$ か ら $t_{2}$ までの範囲で $\left(r_{0}^{2} / 4 a t\right)$ が十分小さければ，(3)式から次 式が導かれる。

$$
\Delta T_{2}-\Delta T_{1}=\left(\frac{q}{4 \pi \lambda}\right)\left\{\ln \left(\frac{t_{2}}{t_{1}}\right)\right\}
$$

ここに $\Delta T=\theta-\theta_{\infty}$ である。したがって，熱伝導率 $\lambda$ は次式で 示される。

$$
\lambda=\left(\frac{q}{4 \pi}\right) /\left\{\frac{\left(\Delta T_{2}-\Delta T_{1}\right)}{\ln \left(\frac{t_{2}}{t_{1}}\right)}\right\}
$$

すなわち, 実験で対数時間に対するプローブ表面温度の上昇を 計測すれば, 媒体の入が求まることになる17)。ただし， $\Delta T$ と $\ln (t)$ との間に直線関係が得られていることが必要である.

\section{2 試料}

供試試料には，市販されているフロートガラスを用いた。そ の基本組成を表 1 に示す。また，この基本組成をべースとし， 着色成分を含有させたフロートガラスも試料とした。すなわ ち，透明のガラス（以後， CFL と表記）, ブロンズ色のガラス

Table 1. Basic Chemical Composition of Samples

(mass\%)

\begin{tabular}{ccccccc}
\hline $\mathrm{SiO}_{2}$ & $\mathrm{Al}_{2} \mathrm{O}_{3}$ & $\mathrm{Na}_{2} \mathrm{O}$ & $\mathrm{K}_{2} \mathrm{O}$ & $\mathrm{MgO}$ & $\mathrm{CaO}$ & Others \\
\hline 72 & 2 & 13 & 1 & 3 & 8 & 1 \\
\hline
\end{tabular}

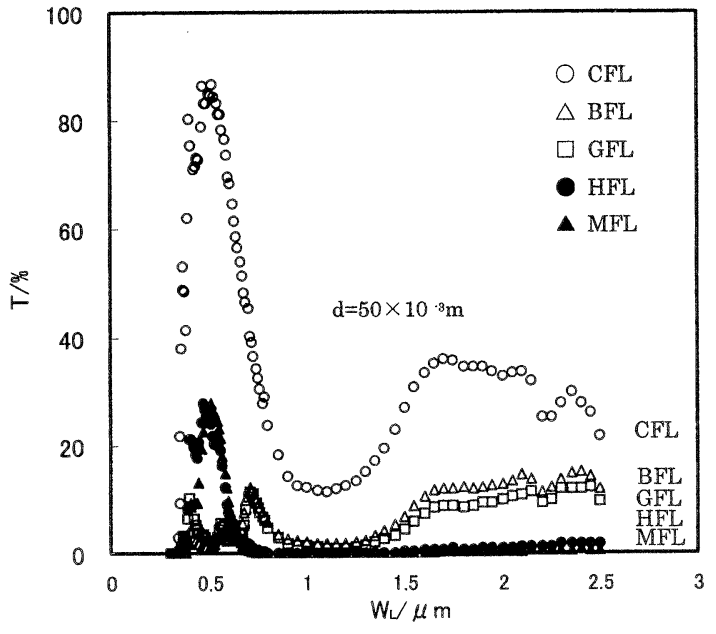

Fig. 1. Optical transmission spectra of glass samples with wavelength $W_{\mathrm{L}}$.

(以後, $\mathrm{BFL}$ ), グレ一色のガラス (以後, $\mathrm{GFL}$ ), 青色のガラ ス (以後, $\mathrm{HFL}$ ) 及び緑色のガラス (以後, MFL) の合計 5 種類のガラスを試料とした．それぞれのガラスの主な物性值を 表 2 に, その光学特性（板厚 $d: 50 \mathrm{~mm}$ ）在図 1 に示す。な 扮，光学特性は，日立製作所製自記分光光度計U-3400 で測 定し，反射の影響18)を考慮した内部透過率として示した。

ガラス試料は，以下のようにして作製した。すなわち，直径 が100 mm で高さが $170 \mathrm{~mm}$ の白金るつぼにガラスカレットを 投入し， $1750 \mathrm{~K}$ で溶融した後，泡を取り除くための清澄工程 及び徐冷工程を経て，円柱状のガラス試料を得た。な押，白金 るつぼの中に入れたままのガラス試料を再加熱して測定したの で，試料作製時及び測定時の白金るつぼは同じである.

\section{3 装 置}

測定装置の概要を図 2 (a) 及び (b) に示す。装置は, 電気炉 $\mathrm{A}$, ガラス試料 $\mathrm{B}$, 試料容器 $\mathrm{C}$, 熱伝導率測定用プローブ $\mathrm{D}$, 定出力電源 $\mathrm{E}$, デジタルデータ記録装置 $\mathrm{F}$ 及びパーソナルコ ンピューターGなどから構成されている。

プローブの詳細を図 2(b)に示す。プローブは外径 $2 \mathrm{~mm}$, 有効長さ $120 \mathrm{~mm}$ の白金ロジウム管内に, 発熱用が 1 本, 及び 温度検知用が 3 本の合計 4 本のシース熱電対（白金-白金ロジ ウム）が挿入されている. 温度検知用の 3 本の熱電対は測定 感度を上げるため, 直列に結線しているので, 最大 3 倍の熱

Table 2. Physical Properties and $\mathrm{Fe}_{2} \mathrm{O}_{3}$ Contents of Samples

\begin{tabular}{lcccccc}
\hline Sample name symbolized & & CFL & BFL & GFL & HFL & MFL \\
\hline Density & $\rho / \mathrm{Mgm}^{-3}$ & 2.50 & 2.49 & 2.49 & 2.49 & 2.49 \\
Refractive index; $\mathrm{n}_{\mathrm{d}}(588 \mathrm{~nm})$ & $\mathrm{n}_{\mathrm{d}} / 588 \mathrm{~nm}$ & 1.52 & 1.52 & 1.52 & 1.52 & 1.52 \\
Visible Transmittance $\left(\mathrm{d}=5 \times 10^{-3} \mathrm{~m}\right)$ & $\mathrm{T} / \%$ & 89.3 & 63.9 & 64.3 & 77.5 & 77.0 \\
Softening point & $\mathrm{Ts} / \mathrm{K}$ & 1006 & 1007 & 1013 & 1014 & 1005 \\
Transition point & $\mathrm{Tt} / \mathrm{K}$ & 828 & 828 & 830 & 830 & 825 \\
Thermal expansion coefficient & $\alpha / \times 10^{-7} \mathrm{~K}^{-1}$ & 86 & 86 & 86 & 86 & 87 \\
Contents of Fe2O3 & $\mathrm{L} / \mathrm{mass} \%$ & 0.08 & 0.21 & 0.23 & 0.43 & 0.56 \\
\hline
\end{tabular}




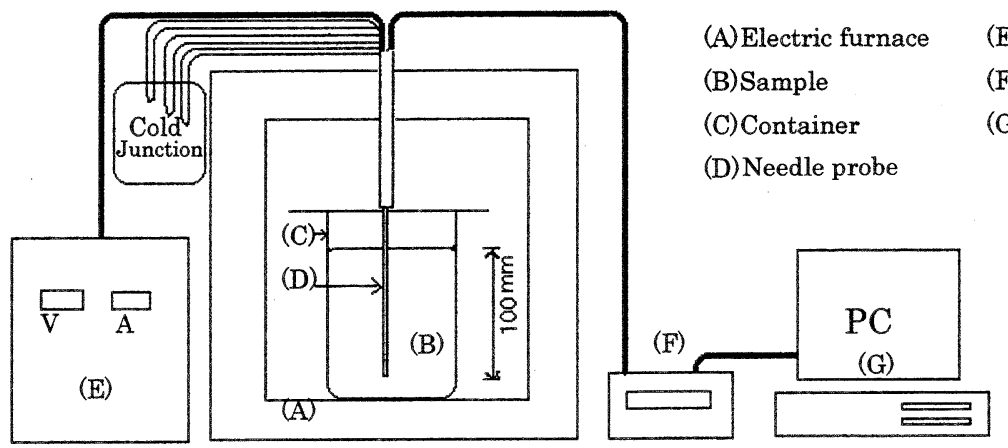

(a) Schematic diagram of measurement system

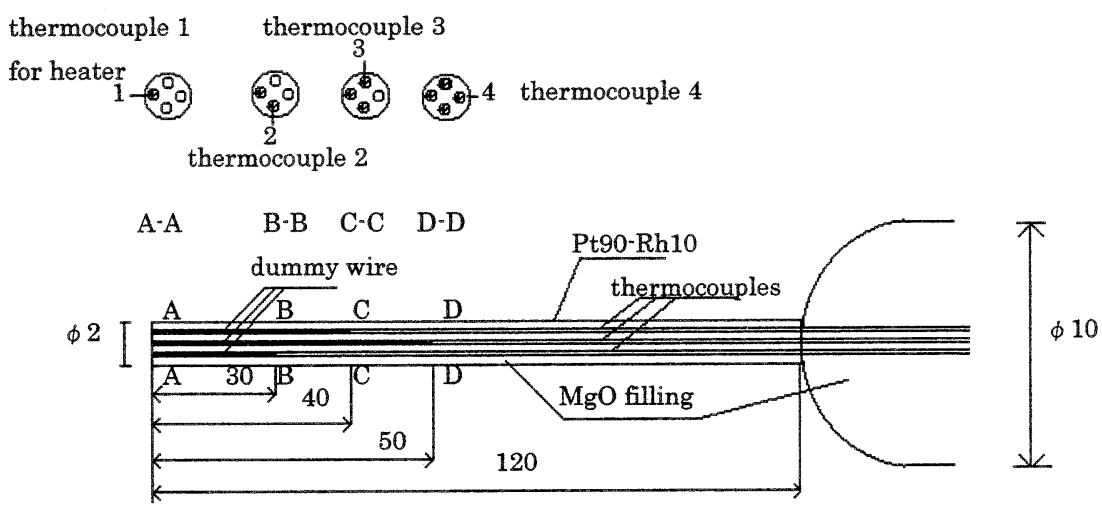

(b) Details of the thermal conductivity probe

Fig. 2. Schematic diagram of the measurement equipment.

電堆として用いることができる，また，その間隙は酸化マグネ シウム粉末で充填されている.

電気炉は, 試料の温度を任意の温度まで加熱し, 一定の温度 で保持した。なお，所定の設定温度に括ける变動は， $\pm 0.2 \mathrm{~K}$ 以内であった。ガラス試料内に挿入したプローブに所定の時 間，一定の電力を供給する定出力電源は，特注品である。その 電力のばらつきの範囲は $\pm 0.3 \%$ 以内であった。デジタルデー タ記録装置としてはアドバンテスト製多チャンネルデジタルボ ルトメーターTR2724 型を用いた。

また，パーソナルコンピューターは，プローブへの電力供給 及び TR2724 記録装置の管理のほか, プローブの温度変化を 表示し，その記録も行った。

\section{4 測定方法}

$1750 \mathrm{~K}$ で溶融したガラスを $1570 \mathrm{~K}$ まで降温し，液体状態に あるガラスの中心部に上方からニードルプローブを挿入した 後, 所定の温度まで下げた。本測定では, 測定領域を室温から $1173 \mathrm{~K}$ までとした． 2 本の熱電対でガラス試料の温度が一定 となったことを確認した後, プローブに熱量 $q$ を与え, その 直後からのプローブ表面の温度変化を測定した．なお，測定時 には，ガラス試料上面からの輻射による䛊差を小さくするた め, 白金の示たを被せて, 試料の底面及び側面とほぼ同様の状 態になるようにした。

プローブ法では温度検出部であるニードルプローブ部と試料 との接触状態が重要であり, その接触状態が悪いと測定誤差の 大きな要因となる。しかし, 本測定においては, 液体状態のガ ラスにプローブを挿入したため，その接触状態は極めて良く， 問題ないと考えられる. 実験データを採取するに当たっては数 回の予備測定を行ったが，温度上昇線図の再現性及び直線性が

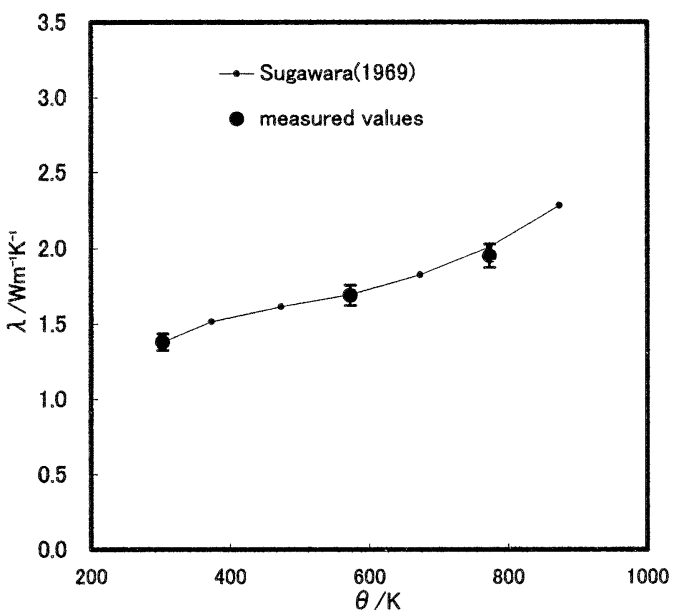

Fig. 3. Variation of thermal conductivity with temperature for fused quartz.

極めて良いことから接触による問題はほとんどないと推察され る. 加熱は, 試料温度が一様かつ平衡状態に達したことを確 認19)した後, 行った. また, プローブの加熱時間は15 min $(900 \mathrm{~s})$ とし, 同じ設定温度で 3 回の測定を行った。

また, 予備実験として高純度 $\left(\mathrm{SiO}_{2}: 99.99 \%\right)$ 石英ガラス の円柱状試料を用いてプローブ及び測定システムの検定を行っ た. その結果を図 3 に示す. 石英ガラスの熱伝導率の測定值 は, $303,573 \mathrm{~K}$ 及び773 K でそれぞれ $1.38,1.69$ W/ (m·K), 及び1.95 W/(m·K) であり, Sugawaraの測定值 ${ }^{20)}$ との差異 が $5 \%$ 以内であることを確認した。 


\section{3. 結果及び考察}

図 4 (a), (b)に各試料の温度上昇線図の例を示す。四 4(a) は $\mathrm{CFL}$ ，(b)はBFL の結果である。縌軸はガラス試料に熱量 $q$ を 与えたときのプローブの温度上昇 $\Delta T$, 及び横軸は測定開始か らの経過時間 $\ln (t)$ である。たたし，縦軸の原点は各線図が 重ならないように少しずつ移行させてある。なお，qは熱伝導

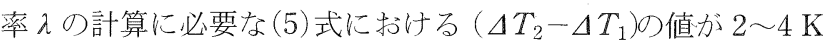
程度となるよう，測定のたびに変化させたので，その值も同時 に示した，以下，この結果に基づき，考察する。

\section{1 プローブの温度上昇線図}

2.1節で述べたように，プローブ法では $\Delta T と \ln (t)$ の間で 得られた直線関係から熱伝導率を算出する。本測定に打いて は， $\Delta T$ と $\ln (t)$ との関係がその測定温度により単純な直線関 係を示さなかった。すなわち，室温から $573 \mathrm{~K}$ までの温度範囲 では， $\Delta T$ と $\ln (t)$ との間にほぼ直線関係が得られたが， $773 \mathrm{~K}$ 以上の温度域では測定時間後半で温度上昇速度が緩やかに減少 していった。この現象は，今回測定した 5 種類のすべてのガ ラスに認められた。与えた熱量が異なるために温度上昇の勾配 はそれぞれ異なるが， $773 \mathrm{~K}$ 以上の測定時間後半で， $\Delta T / \mathrm{ln}$
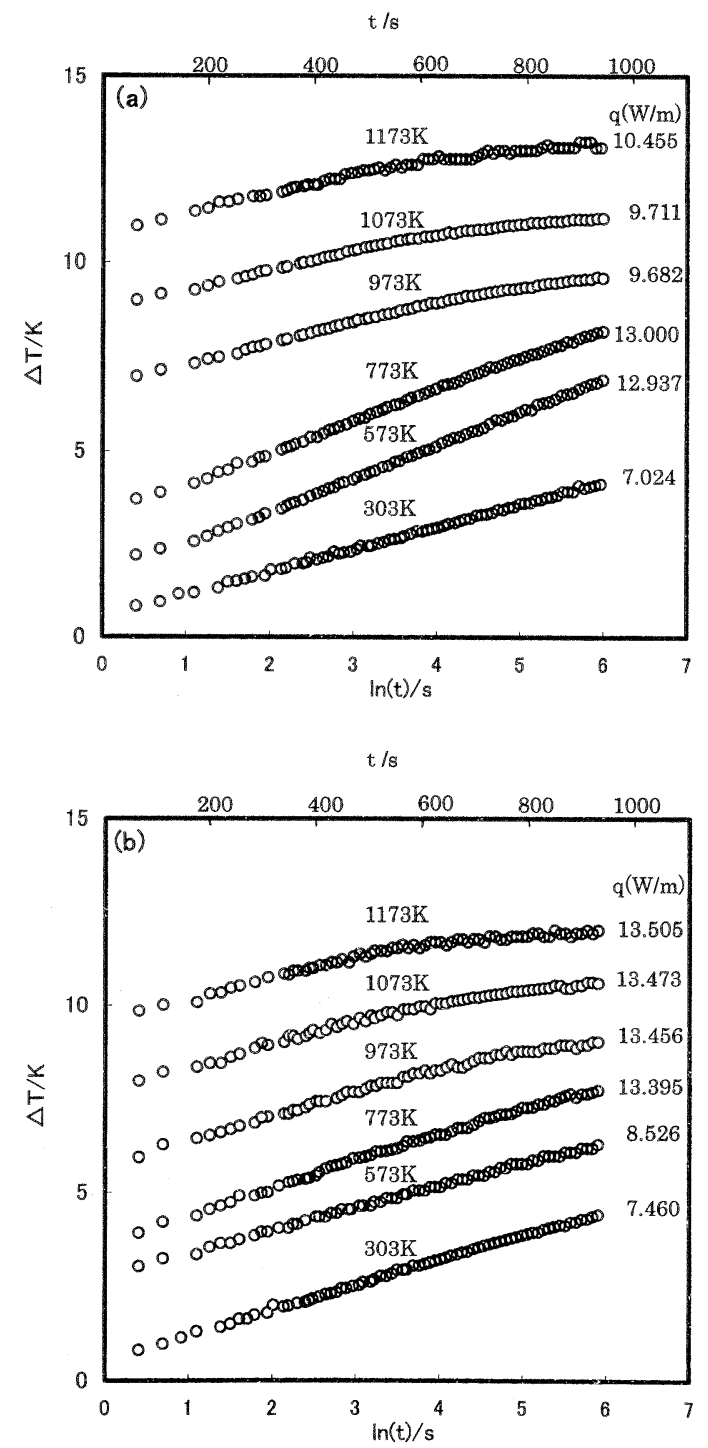

Fig. 4. (a) $\Delta T$ versus $\ln (t)$ curves for sample CFL and (b) $\Delta T$ versus $\ln (t)$ curves for sample BFL. （t）の勾配が小さくなる傾向は同様であった，更に，この傾向 は高温度レベルになるほど顕著であった。

この理由として，プローブ自体もしくはガラス試料内で発生 する輻射, 及びガラス試料内の対流発生が考えられる. 今回の 場合は特に前者の影響が大きいと考えられる。ガラスはほとん ぞのものが短波長域 $\left(W_{\mathrm{L}} \fallingdotseq 0.25 \sim 2.5 \mu \mathrm{m}\right)^{21)}$ の輻射線に対し て半透明である。プローブから発したこの波長域の輻射エネル ギ一（の一部）は，加熱開始直後からの温度差 $\Delta T$ が大きく なるほどガラス媒体を暖めずに透過し外に逃げ去る。これが $\Delta T-\ln (t)$ 曲線後半の温度变化となって現れる。この傾向は 温度レベルが高いほど, 輻射エネルギ一の重要部分が短波長側 に移行するため顕著となる。しかし, 試料内要素で発生した輻 射エネルギーは試料内のほかの要素で透過・吸収されながら移 動していくが，それが試料内要素の温度にどのように影響する のかは今後の研究課題である。また, 上述の対流の影響は高温 度レベルでは当然予想されるが，図 4 の $\Delta T-\ln (t)$ 曲線の滑 らかな変化から，この温度レベルではその影響はまだ小さいと 考えた方が妥当であ万う。

以上の理由から，本測定においては，熱伝導率を算出するた めの温度上昇の傾き $\Delta T / \ln (t)$ は，比較的測定時間経過が短 く，加 $\Delta T$ が小さな領域に抢いて得られる直線関係から求 めた。更に， $\Delta T$ の小さな領域とはいえ，プローブで発生する エネルギーには輻射エネルギーが含まれているので，この量に ついては後述する補正を行った。なお，直線部分の判定ならび に熱伝導率の算出は，出口らの方法 ${ }^{19)} に$ 基づいて行った。

\section{2 フロートガラスの熱伝導率}

CFLの室温から $1173 \mathrm{~K}$ に抢ける熱伝導率 $\lambda$ の測定結果を 図 5 に示す。図 5 には荒木ら ${ }^{7)}$ 及び栗山ら 22)のソーダ・ライ ム・シリカガラスでの測定結果も各々 $\triangle$ 印及びロ印で示した。 本研究の測定值はこれらの文献值と室温から573 K まででは良 く一致したが， $773 \mathrm{~K}$ では文献值よりも約 $20 \%$ 小さな值を示 した。ガラス組成に依存する弾性体から粘弾性体への变化，そ してプローブ及びガラス媒体内で発生する輻射エネルギーの影 響が寄与していると思われる。

5 種類のフロートガラスにおける室温から1173 K の測定結 果を図 6 に示す。失，以上の值を一括して表 3 に示した。こ れらの熱伝導率值については，以下の方法により，ガラス組成 及び輻射損失の影響に対する補正を試みた。すなわち，今回試 料として用いたガラスの基本組成を表 1 に示したが，そのガ ラス試料にはわずかながらガラス組成差がみられた。この組成 差については，加成式から熱伝導率に与える影響を知ることが できる、そこで，Ratcliffe $\mathrm{e}^{6)}$ の加成式を用いて，今回試料とし て用いたガラスの組成の違いからくる熱伝導率の差異を計算し てみた。熱伝導率の計算は室温条件で行った。その結果は，得 られた值の0.3\%以下であった。(1)式からより正しい熱伝導率 を求めるためにはプローブの発生熱量 $q$ から，そのうちの輻 射損失熱量 $q_{\mathrm{r}}$ を差し引き補正しなければならない。 $q_{\mathrm{r}}$ の算出 は近似解析 ${ }^{23)}$ で行った。 $q_{\mathrm{r}}$ を算出した後, $q$ の補正值 $q^{*}$ 次式

$$
q^{*}=q-q_{\mathrm{r}}
$$

から求め, (1)式の $q$ を $q^{*}$ で置き換えて熱伝導率を求めた結果 が図 5 と図 6 である。この補正による差は高温になるほど大 きく, CFL ガラ久の場合, 最大 $(\theta=1173 \mathrm{~K})$ で補正前の $\lambda$ に対して $3 \%$ の減少であった。

図 6 に示すように熱伝導率は温度の上昇とともに増大した。 軟化点以下での熱伝導率は直線的に増加したが，それ以上では 温度上昇とともに増加の割合が大きくなるようにみえる。この 増加に関する温度依存性については今後の検討課題である。 
今回, プローブ法で測定した 5 種類のフロートガラスの熱 伝導率がいずれも同様の值を示したことは, 極めて興味深い。 これまで, 着色ガラスの熱伝導率は見掛けの熱伝導率のデータ として示されることが多かったため，透明のガラスと大きく異 なっていた12)からである。

ガラス媒体中での鉄イオンなどの遷移金属イオンが熱伝導率 へ及ばす影響8については，特に輻射伝熱として寄与すること

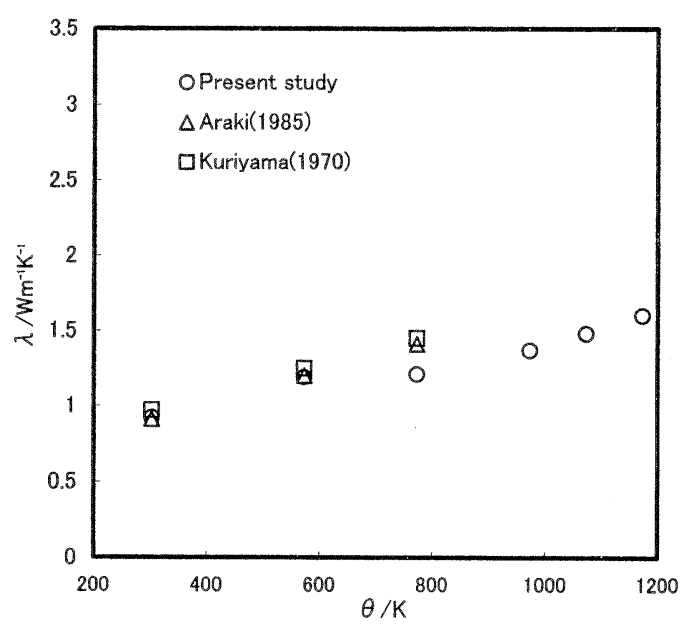

Fig. 5. Variation of thermal conductivity with temperature for sample CFL.

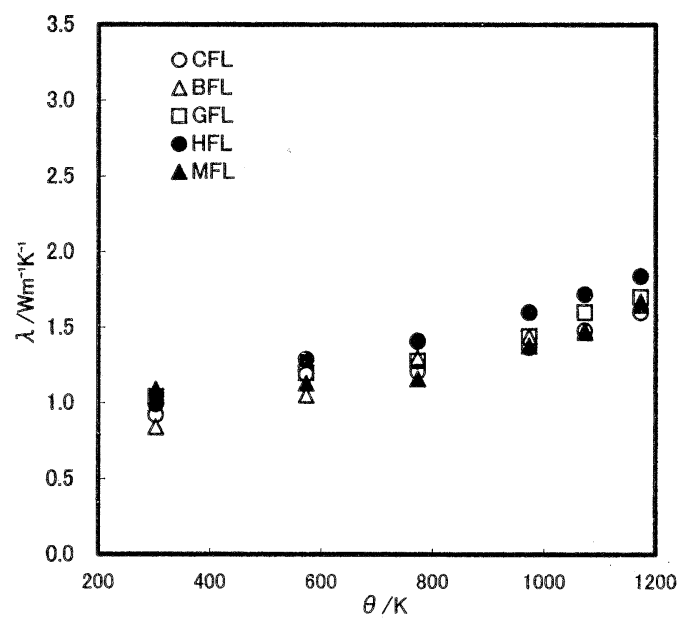

Fig. 6. Variation of thermal conductivity with temperature.
が実験的に示されている。しかし，今回の実験に抽て，鉄イ オン含有量を酸化物としてみたときに $0.08 \sim 0.56 \%$ まで変化さ 世たことになるが, 得られた熱伝導率にその差は認められな かった、詳細は次節で述べるが, 鉄イオンを $0.56 \%$ まで含有さ せたソーダライムガラスの場合の輻射熱伝達值が極めて大きい とは考えられない。したがって, 今回の測定温度域に打けるプ ローブ法による測定では, ガラス組成の主成分のみによってそ の值が定まることになり, 着色成分は熱伝導率に影響を与えて いないことになる。この結果から, 本実験で用いられたガラス 内の熱移動が，輻射伝熱によるものではなく，伝導伝熱による ものと考えられる。

\section{3 見掛けの熱伝導率の推定}

今回得られた熱伝導率は真の熱伝導率と推察され，見掛けの 熱伝導率 (=真の熱伝導率十輻射熱伝導率) と異なっている. しかし，見掛けの熱伝導率も実用上極めて重要な值である。そ こで, 前節で得られた結果を基に見掛けの熱伝尊率を推定した。 3.2節でも述べたように, 真の熱伝導率はすべてのフロート ガラスでほぼ同じ值であった。したがって, 個々のガラスの輻 射熱伝導率を求めれば, 見掛けの熱伝導率を得ることができ る。高温域において真の熱伝導率が実際に測定された例は, 著 者らの知る限り, 報告されていない。本報では計算から見掛け の熱伝導率を求めた Genzel の結果 ${ }^{12)}$ を利用することにより, 各種ガラスの見掛けの熱伝導率を推定した。

ガラス媒体内で輻射エネルギーが，工ネルギ一伝達に大きな かかわりをもつ領域は赤外域 $(0.8 \sim 2.5 \mu \mathrm{m})$ であり，この範 囲での透過率と熱エネルギーの相関を知ることが重要である。 ガラスでの透過量はその板厚が厚くなるにつれて小さくなり, ゼロに近づく．このときの板厚を求めることにより, ガラスが 一時的に吸収する熱エネルギ一を仮定することができる。図 1 から明らかなように, それぞれのガラスの赤外域での内部透過 率曲線には比較的相似性がある。 そこで, 赤外域のほぼ中間で ある $1.5 \mu \mathrm{m}$ の波長をそれぞれのガラスにおける透過率の相対 的な代表值とし, 透過率の変化と板厚の関係を求めた。それぞ れのガラスに拈ける相対透過率 $\left(T_{\mathrm{r}}\right)$ と板厚 $(L)$ との関係を 図7 に示す.

$T_{\mathrm{r}}$ は $L$ が大きくなるにつ机て下がり，Lがある值になると ゼロに近づく，今回の測定では， $T_{\mathrm{r}}$ が $0.3 \%$ になるまでの厚さ を輻射伝熱の有効厚さ $\left(L_{0}\right)$ と定めた。この $L_{0}$ の值は, それ ぞれのガラスで異なり，例えば CFL では $270 \mathrm{~mm}, \mathrm{MFL}$ では $45 \mathrm{~mm}$ であった。すなわち, CFL では厚さ方向に $270 \mathrm{~mm}$ ま で発熱体の輻射エネルギーを透過するが，MFLでは $45 \mathrm{~mm}$ で ほぼ透過しなくなることを意味している。

Table 3. Measured Values of the Thermal Conductivity at Temperature Range 303-1173 K with Reference Values from Literatures

$\lambda / \mathrm{Wm}^{-1} \mathrm{~K}^{-1}$

\begin{tabular}{|c|c|c|c|c|c|c|c|}
\hline Temperature/K & CFL & BFL & GFL & HFL & MFL & Araki(1985) & Kuriyama(1970) \\
\hline Ratcliffe & 0.9 & 0.9 & 0.9 & 0.9 & 0.9 & & \\
\hline 303 & 0.9 & 0.8 & 1.0 & 1.0 & 1.1 & 0.9 & 1.0 \\
\hline 573 & 1.2 & 1.1 & 1.2 & 1.3 & 1.1 & 1.2 & 1.3 \\
\hline 773 & 1.2 & 1.3 & 1.3 & 1.4 & 1.2 & 1.4 & 1.5 \\
\hline 973 & 1.4 & 1.4 & 1.4 & 1.6 & 1.4 & & \\
\hline 1073 & 1.5 & 1.5 & 1.6 & 1.7 & 1.5 & & \\
\hline 1173 & 1.6 & 1.7 & 1.7 & 1.8 & 1.7 & & \\
\hline
\end{tabular}




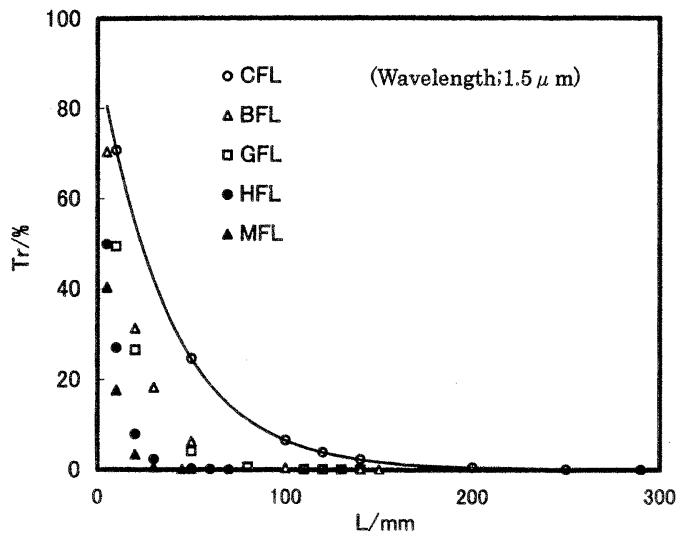

Fig. 7. Relation between transmittance $T_{\mathrm{r}}$ and plate thickness $L$.

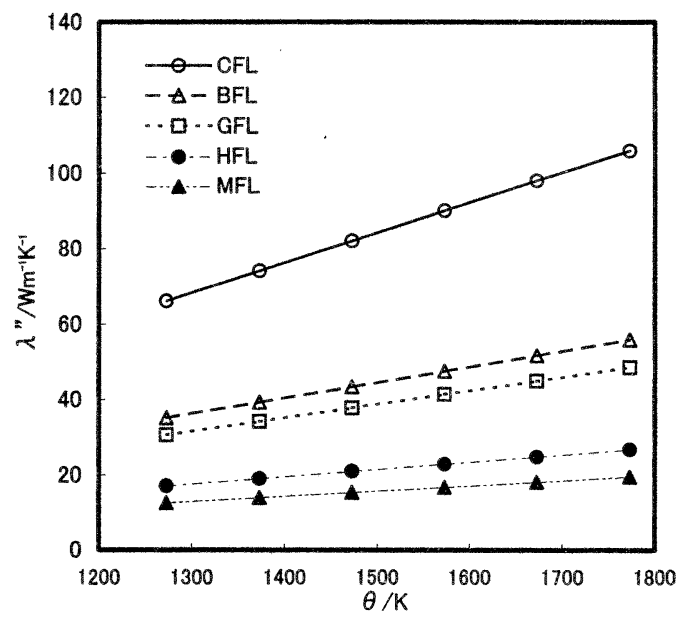

Fig. 8. Variation of apparent thermal conductivity with temperature.

この $L_{0}$ から，輻射エネルギ一の透過能に基づく係数 $a$ を求 め, 着色ガラスの見掛けの熱伝導率 $\lambda^{\prime \prime}$ を推定した。 $\lambda^{\prime \prime}$ は(7)式 で定義した。

$$
\lambda^{\prime \prime}=\lambda^{\prime}+a\left(\lambda_{G}-\lambda^{\prime}\right)
$$

ここで,

$\lambda^{\prime}:$ 図 6 から得られた CFLの熱伝導率

$\lambda^{\prime \prime}:$ CFL を基準とした見掛けの熱伝導率

$\lambda_{\mathrm{G}}:$ Genzel の式から求めた見掛けの熱伝導率

$a:$ 輻射エネルギーの透過能に基づく係数

である。 $a$ は CFLの $L_{0}$ を基準として着色ガラスの $L_{0}$ との比 から求めた。 $a$ は CFL, BFL, GFL, HFL, MFL の順に, 1.00 , $0.52,0.45,0.24,0.17$ となった。

各種ガラスでの温度と見掛けの熱伝導率との関係を図 8 に示 す。見掛けの熱伝導率を大きい順に並べると, CFL, BFL, GFL, HFL 及び MFL となった：この傾向は実際の窯をモデリ ングした状況と極めて良く一致しており，その值も妥当性があ るようにみえる。しかし，見掛けの熱伝導率への換算方法を含 め, この詳細な検討は今後の研究課題である。

\section{4. 結 論}

透明のフロートガラス及び主成分がほぼ同様の 4 種類の着色 ガラスを試料とし，プローブ法により室温から $1173 \mathrm{~K}$ までの
温度範囲におけるガラスの熱伝導率を測定したところ, 以下の 結論を得た

（1）測定した 5 種類のガラスの熱伝導率は，いずれもほぼ 同じ值を示し, $573 \mathrm{~K}$ 以下の温度域では, 文献值とも良い一致 を示した。輻射及び対流伝熱の影響の排除を考慮した測定法に より得られた測定值に輻射の補正を行ったので，得られた值は 真の熱伝導率であると推察された。

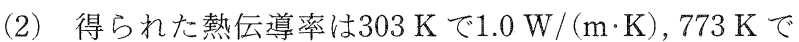
$1.3 \mathrm{~W} /(\mathrm{m} \cdot \mathrm{K}), 973 \mathrm{~K}$ で1.4 W/ $(\mathrm{m} \cdot \mathrm{K}), 1173 \mathrm{~K}$ で1.7 W/(m. K)であった.

（3）軟化点よりも低い温度域では, 熱伝導率は温度の上昇 と之もにほぼ直線的に増加した。それ以上の温度域では増加割 合は，より大きくなる傾向が認められたが，ガラスの熱伝導率 の温度依存性は今後の検討課題である.

(1999年10月 6 日 日本セラミックス協会第12回秋季シンポジウ ムにて発表)

\section{文献}

1) N. Araki, Kikai no Kenkyu, 35, 1121-28 (1983) [in Japanese].

2) G. Ogura, I.-K. Suh, H. Ohta and Y. Waseda, J. Ceram. Soc Japan (Seramikkusu Ronbunshi), 98, 305-07 (1990) [in Japanese].

3) M. Kamimoto, K. Kanenari and Y. Takahashi, Netsusokutei, 8, 115-22 (1981).

4) S. Sakka, "Glass no Jiten," Asakura Shoten (1985) pp. 37475.

5) M. Matveef, G. Matveef and B. Frenkeri, "Glass Kakou Binran," Nisso Tushinsha (1972) pp. 165-69 [in Japanese].

6) E. H. Ratcliffe, Glass Technol., 4, 113-28 (1963).

7) N. Araki and Y. Sasahara, Proc. 22nd National Heat Transfer Sympo. of Japan (1985) pp. 584-86 [in Japanese].

8) S. Sugiyama, M. Shimizu and S. Mochizuki, Kagaku Kougaku, 30, 220-25 (1966) [in Japanese].

9) S. Sasaki, H. Masuda and H. Kou, Proc. 5th Asian Thermophysical Properties Conference, Seoul, Korea (1998) pp. 475-78.

10) W. D. Henderson, J. C. Carling, H. Rawson and A. Blazek, Glass Technol., 24, 127-32 (1983).

11) Yu Fan, Zhang Xinxin and Gao Guangning, Proc. 5th Asian Thermophysical Properties Conference, Seoul, Korea (1998) pp. 199-204.

12) L. Genzel, Glastechn. Ber., 26, 69-71 (1953).

13) H. P. Ebert and J. Fricke, High Temp.-High Press., 3, 655-69 (1998).

14) H. Kiyohashi and K. Banno, High Temp.-High Press., 27/28, 653-63 (1995/1996).

15) JSME, "Netsubusseichi Sokuteiho - Sono Sinpo to Kougakuteki Oyo," Yokendo (1991) pp. 49-67 [in Japanese].

16) H. S. Carslaw and J. C. Jaeger, "Conduction of Heat in Solid," 2nd ed., Oxford Press (1959) pp. 261-62.

17) H. Kiyohashi, Chinetsu Energy, 13, 38-53 (1988) [in Japanese].

18) M. Rubin, Solar Energy Materials, 12, 275-88 (1985).

19) M. Deguti, H. Kiyohashi and S. Suzuki, Shigen Sozai Gakkaishi, 107, 17-22 (1991) [in Japanese].

20) A. Sugawara, Physica, 41, 515-20 (1969).

21) Y. S. Toulonkian and C. Y. Ho, Eds., "TPRC Data Ser., Thermophysical Properties of Matter, Vol. 8," Plenum, New York (1972) pp. 1523-652.

22) M. Kuriyama, K. Katayama, Y. Taguma and Y. Hasegawa, JSME , 41, 3588-95 (1970) [in Japanese].

23) H. Kiyohashi, N. Hayakawa, S. Aratani and H. Masuda, Book of Abstracts, 15th European Conference on Thermophysical Properties, Wurzburg, Germany (1999) p. 241 